\title{
Women's role in Household Food Security in the Rural-Urban Contexts of Sri Lanka
}

\author{
by
}

Chandanee Wasana Kalansooriya

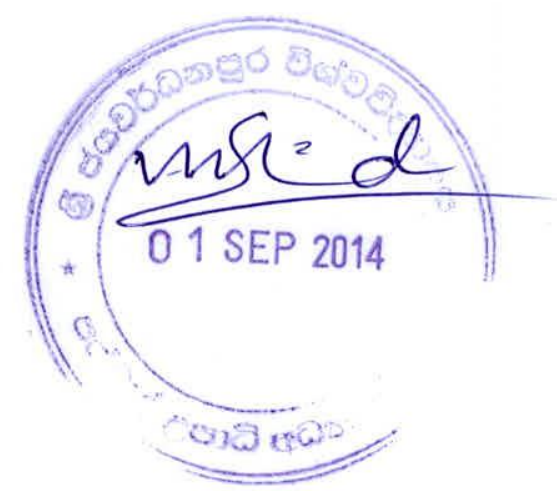




\section{Table of Content}

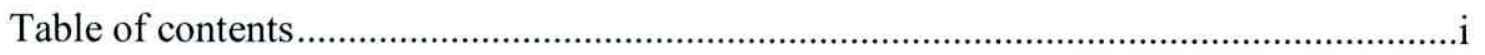

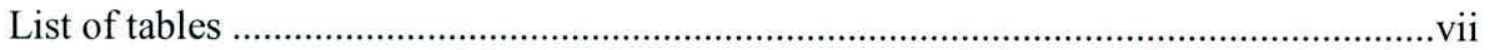

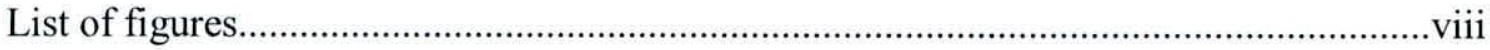

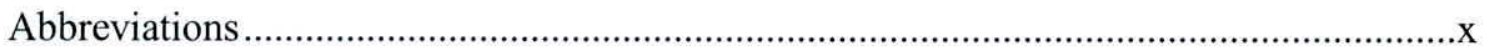

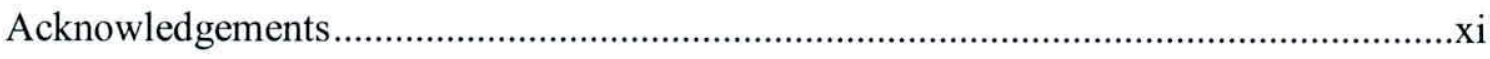

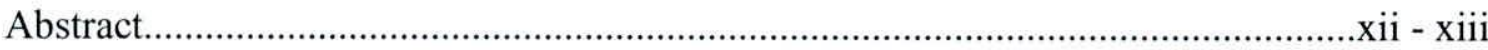

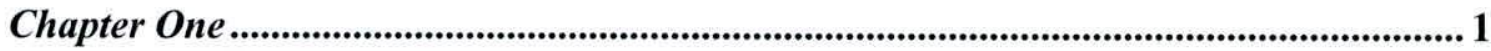

INTRODUCTION

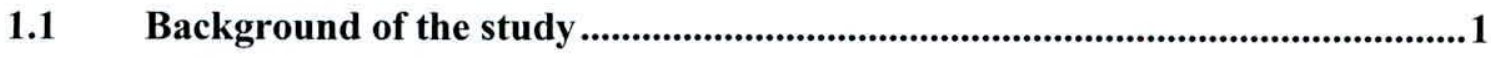

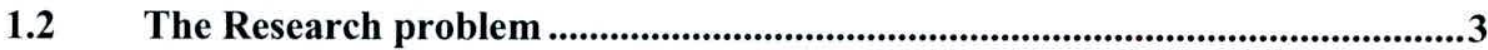

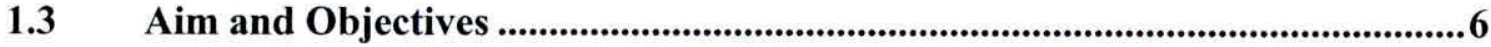

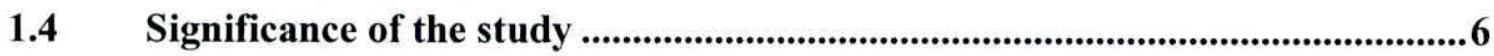

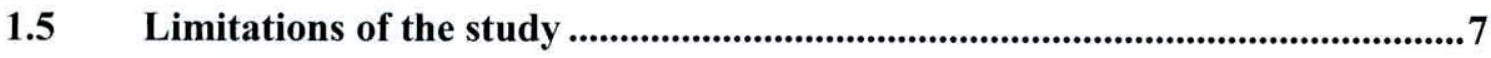

1.6 Organization of the Study

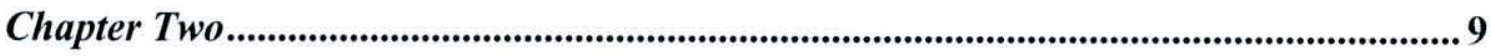

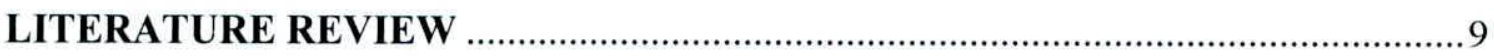

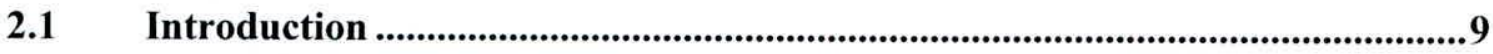

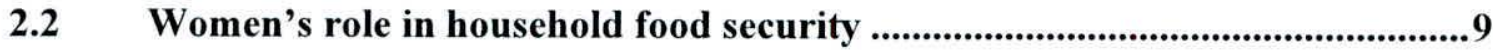

2.2.1 The role of women's employment and income in household food security ........10

2.2.2 Impact of women's education on household food security .................................16

2.2.3 Impact of women's status of the household on household food security.............19

2.2.4 Women's contribution to agricultural food production .....................................22

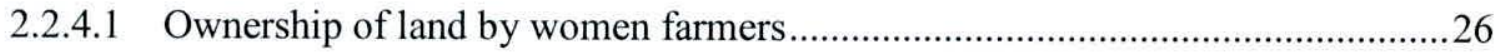

2.2.4.2 Use of new technology by women farmers.......................................................... 30

2.2.4.3 Availability of credit for women farmers .......................................................... 31

2.3 Female household headship and household food security ..............................35

2.4 Rural urban differences of household food security and the role of women42 
2.4.1 Determinants of food security: urban rural differences......................................44

2.4.2 Differences of urban rural food consumption patterns.......................................51

2.5 Summary of the literature .....................................................................................58

2.5.1 Women's income and household food security ..................................................58

2.5.2 Women's education and household food security................................................58

2.5.3 Women's status in the household and household food security ...........................59

2.5.4 Women's contribution to agricultural food production......................................59

2.5.5 Female household headship and household food security .................................60

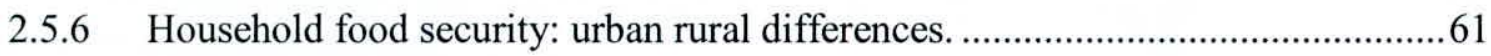

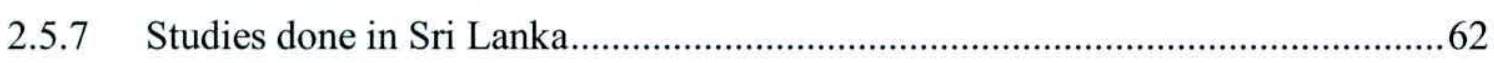

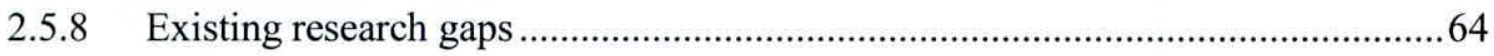

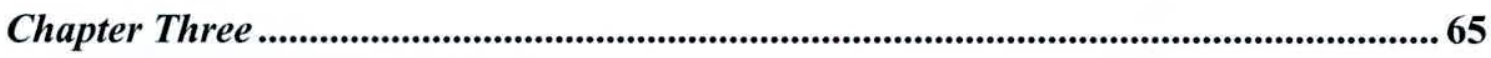

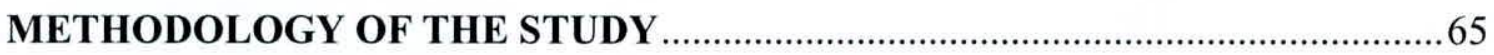

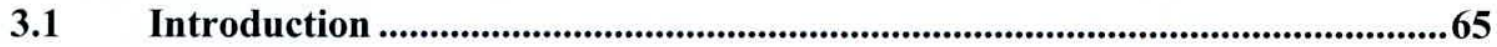

3.2 Women's role in household food security: A conceptual framework...........65

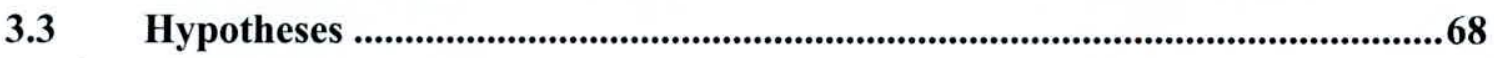

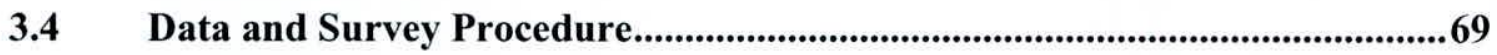

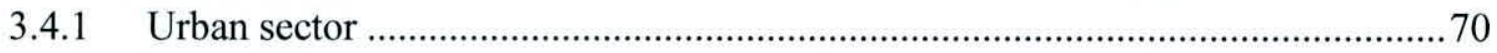

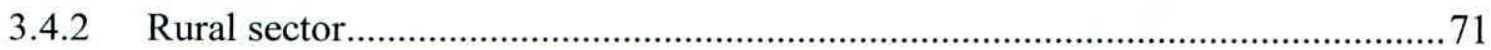

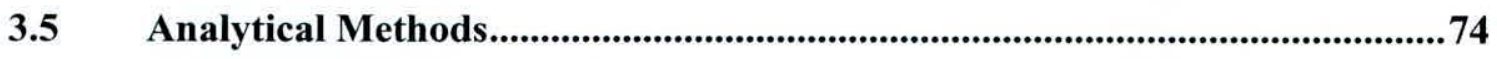

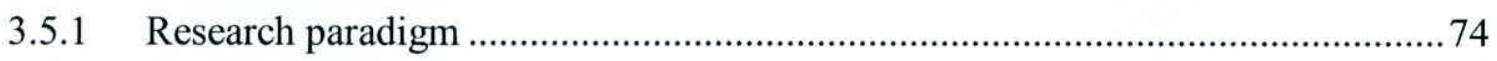

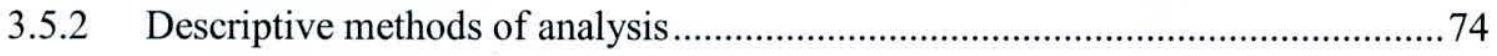

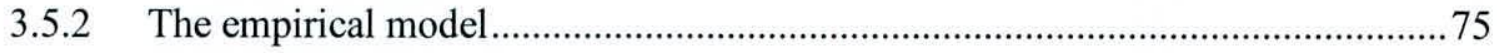

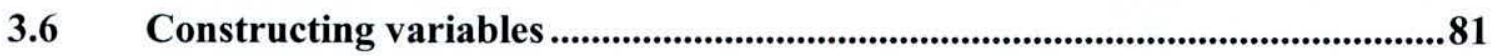

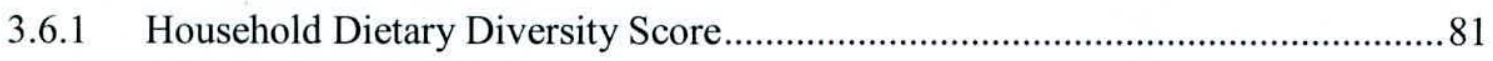

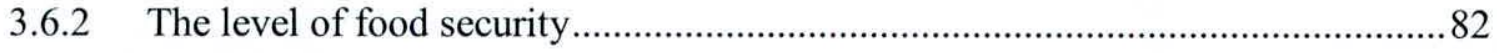

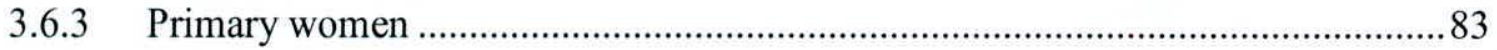

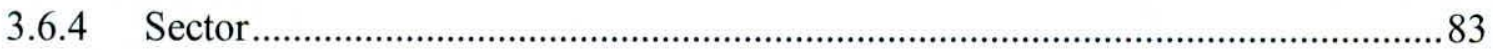

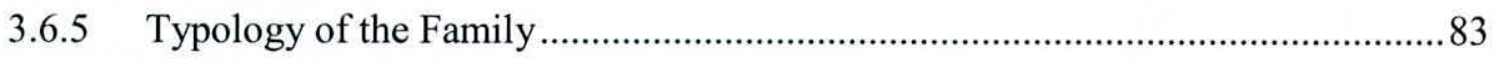

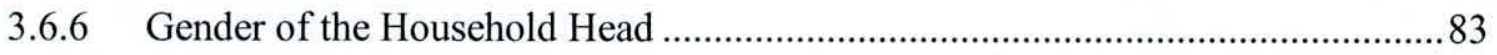

3.6.7 Education of the Household Head/ Education of the Primary women...................84 


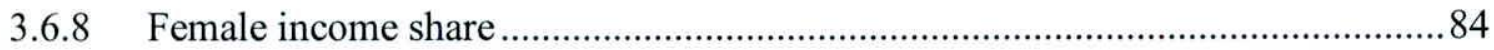

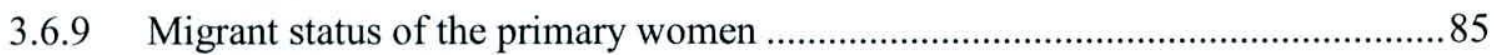

3.6.10 Gender of the person who manage household expenditures ................................ 85

3.6.11 Gender of the person who takes decisions on household income and spending.. 85

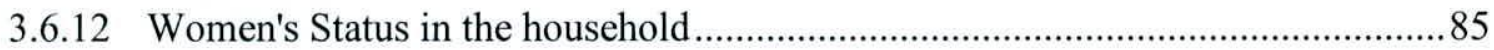

3.6.13 Intention of preparing nutritious food within the household .............................. 86

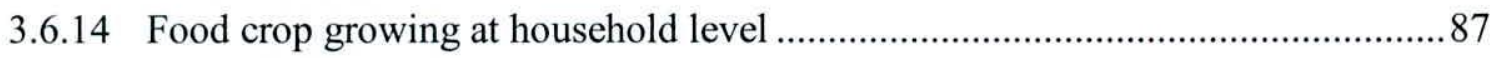

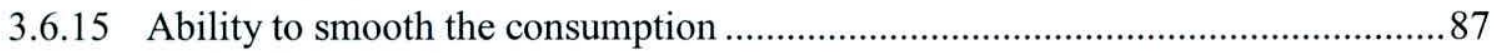

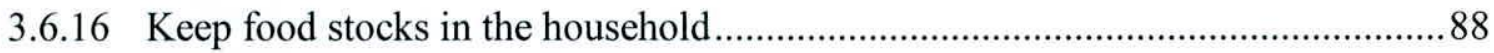

3.6.17 Use indigenous knowledge for household management ..................................... 88

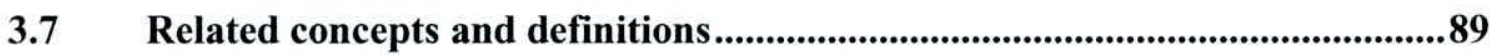

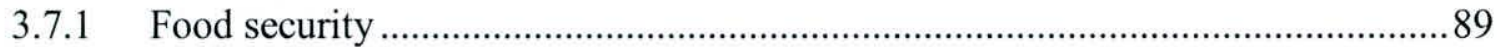

3.7.2 Food security at household level ...........................................................................91

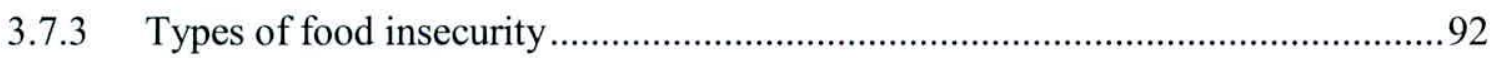

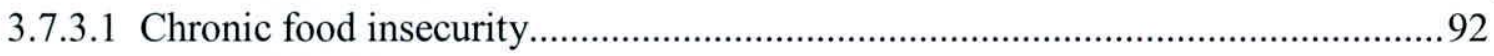

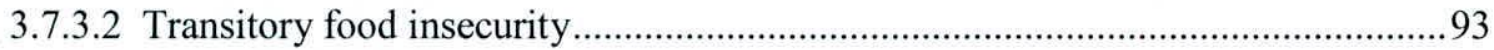

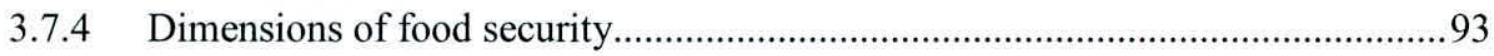

3.7.5 Measuring household food security ....................................................................96

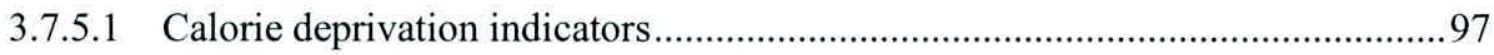

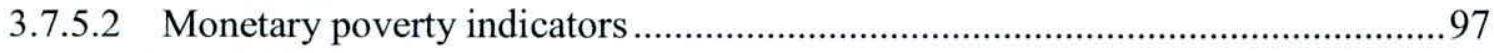

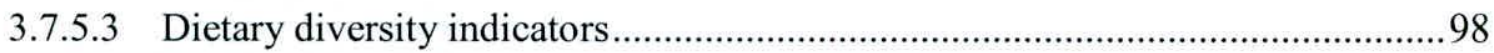

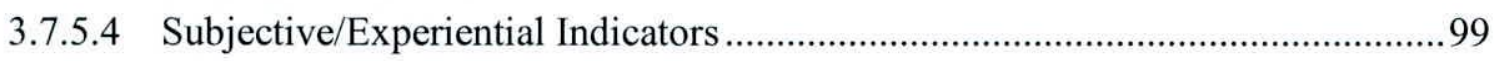

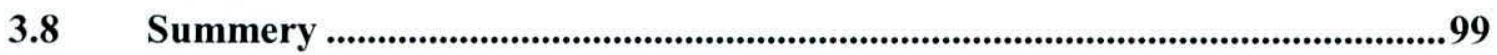

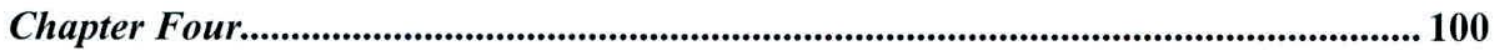

RESULTS OF THE DESCRIPTIVE ANALYSIS................................................... 100

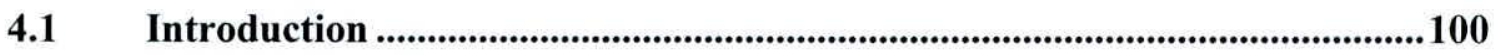

4.2 Socio-economic characteristics of the sample ...............................................100

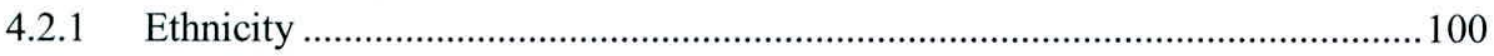

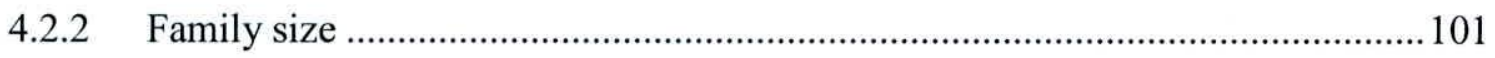

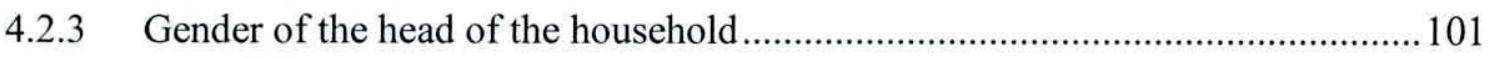

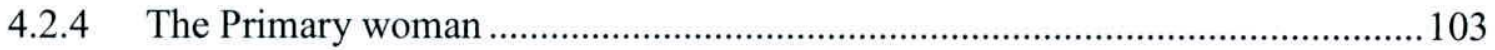




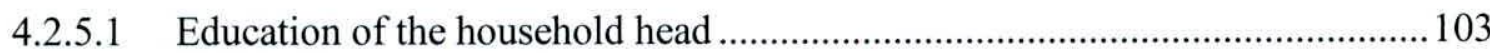

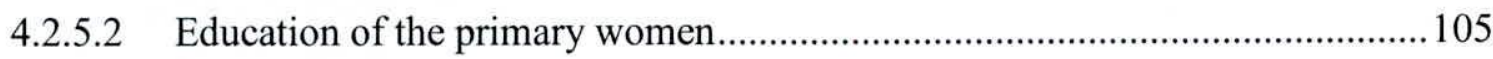

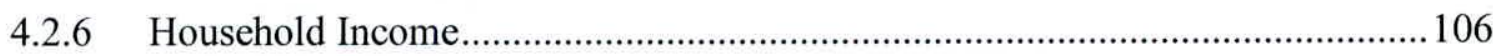

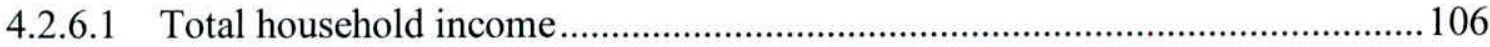

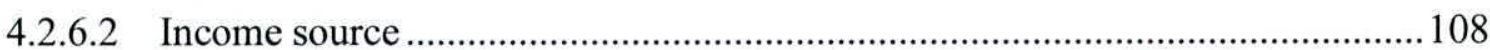

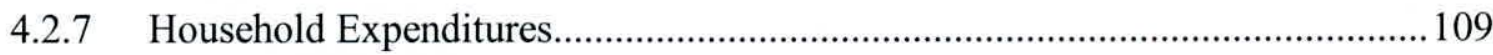

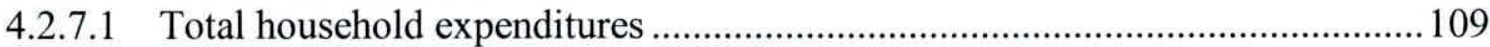

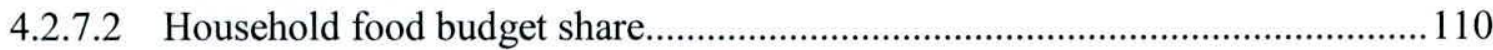

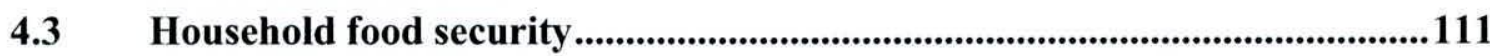

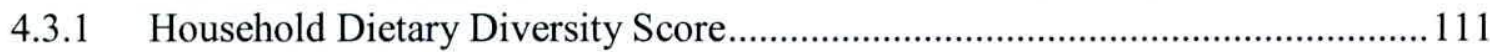

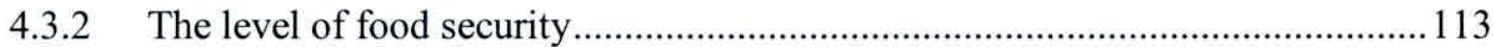

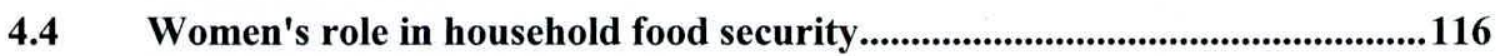

4.4.1 Women's contribution to agricultural food production ......................................116

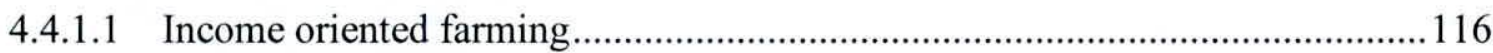

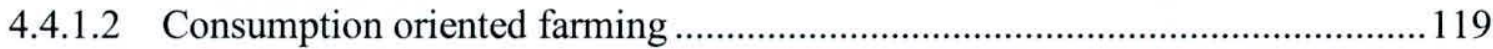

4.4.2 Women's contribution to household income ........................................................ 122

4.4.2.1 Female income in the household..................................................................... 122

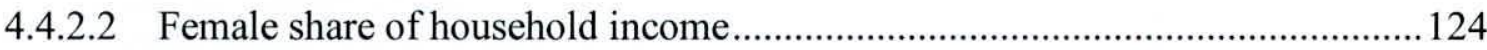

4.4.2.3 Female income share and food security ........................................................ 126

4.4.3 Impact of women's education on household food security................................. 128

4.4.4 Impact of women's status in the household on household food security............129

4.4.5 Women's contribution in managing household expenditures ..............................130

4.4.5.1 Maintaining a smooth consumption..................................................................... 131

4.4.5.2 Maintaining food stocks in the household .......................................................... 135

4.4.5.3 Use indigenous knowledge for household management....................................137

4.4.6 Women's contribution to household food preparation .......................................139

4.4.6.1 Food preparation in the household........................................................................139

4.4.6.2 Household intention on consuming a nutritional diet ...................................... 140

4.4.6.3 Consumption of food prepared outside the home............................................... 143

4.4.7 Women's role and household food consumption differences .............................. 144

4.4.7.1 Consumption differences by sector................................................................. 145 
4.4.7.2 Consumption differences by household total income .......................................146

4.4.7.3 Consumption differences by female share of household income ..................... 147

4.4.7.4 Consumption differences by the education of primary women ........................ 148

4.4.7.5 Consumption differences by the gender of the household head ....................... 150

4.4.7.6 Consumption differences by the person who manage household income .........151

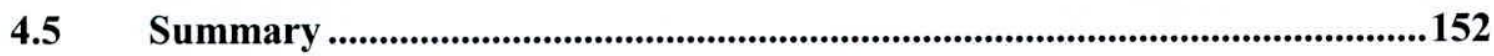

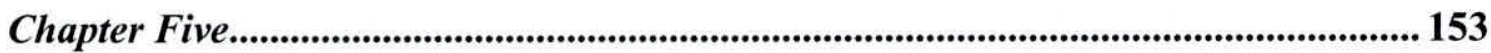

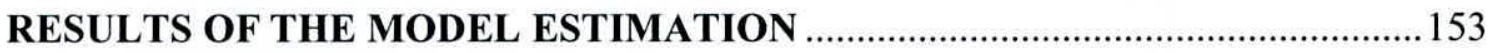

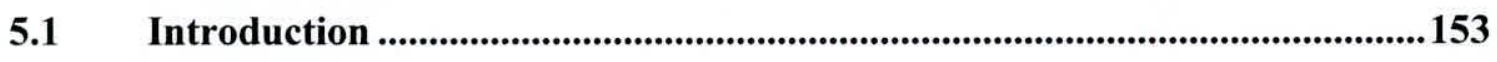

$5.2 \quad$ The specification of the econometric model ...................................................153

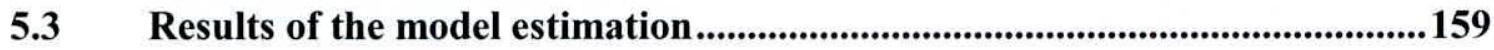

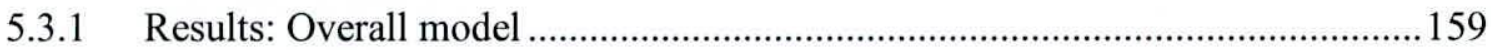

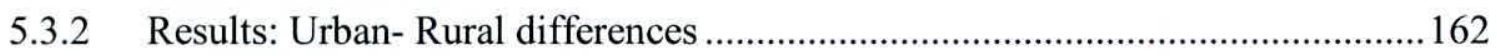

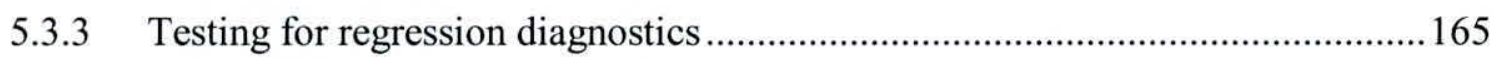

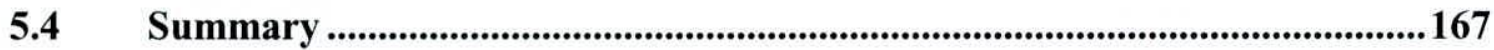

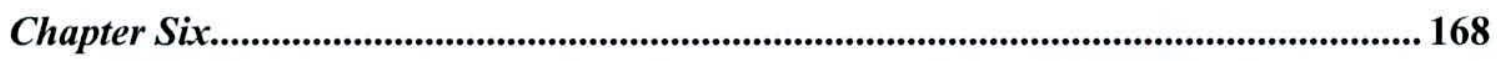

DISCUSSION, CONCLUSION AND POLICY RECOMMENDATIONS .............. 168

Introduction ................................................................................................................168

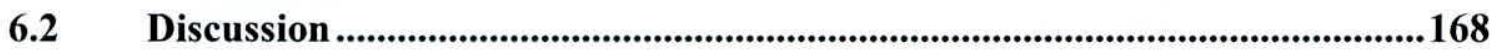

6.2.1 Exploring the women's role in the three dimensions of food security ................ 169

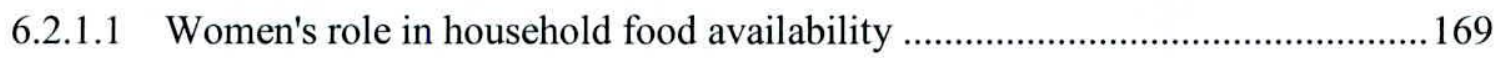

6.2.1.2 Women's role in household food access ......................................................... 171

6.2.1.3 Women's role in household food utilization ................................................. 173

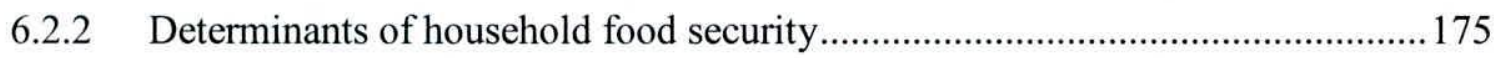

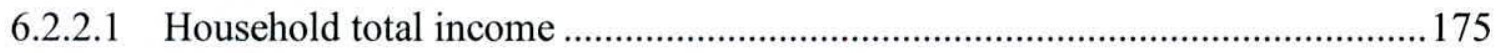

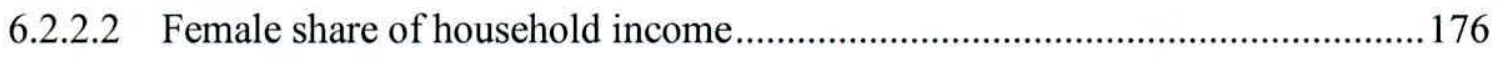

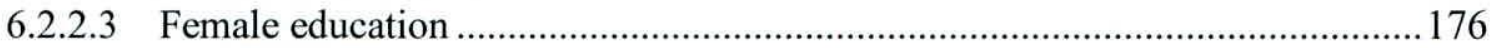

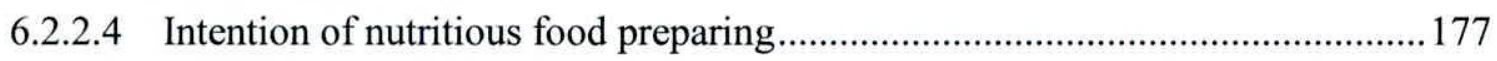

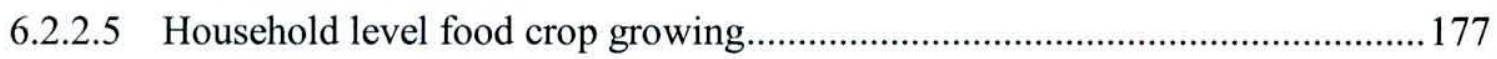

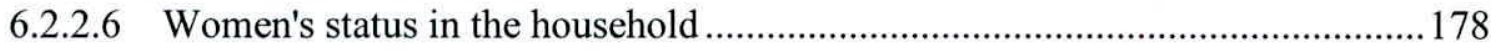




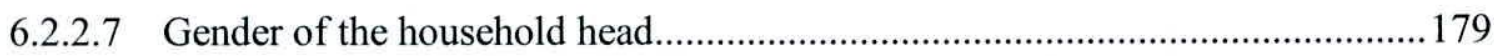

6.2.3 Urban-rural differences of the women's role in household food security ..........180

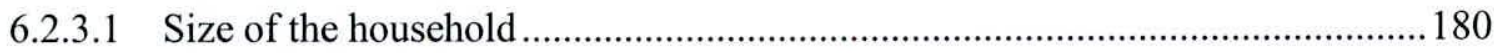

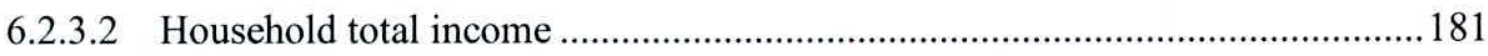

6.2.3.3 Female share of household income............................................................... 181

6.2.3.4 Education of the Primary Women..................................................................... 183

6.2.3.5 The household Intention of preparing a nutritious meal .................................. 183

6.2.3.6 Use indigenous knowledge for household management................................... 183

6.2.3.7 Food crop growing at household level........................................................... 184

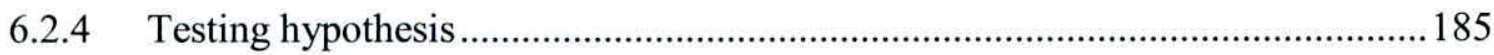

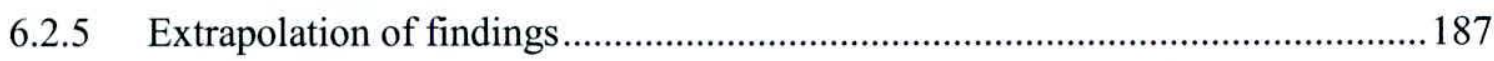

6.3 Conclusion ....................................................................................................................187

6.4 Policy Recommendations ........................................................................................191

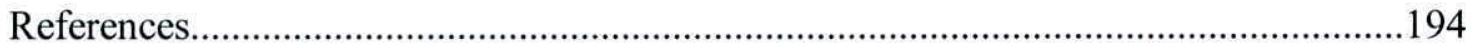

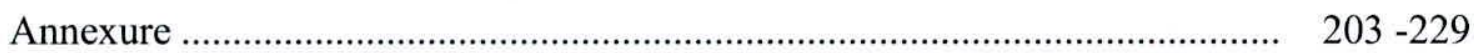




\section{List of Tables}

Table 2.1 Literature summary: Female household headship and household food security

Table 2.2 Literature summary: Urban-Rural differences of food security .61

Table 2.3 Literature summary: Studies in Sri Lanka .62

Table 4.1 Percentage of the consumption of different food groups by sector 145

Table 4.2 Percentage of the consumption of different food groups by income categories.

Table 4.3 Percentage of the consumption of different food groups by female share of household income.

Table 4.4 Percentage of the consumption of different food groups by the education of the primary women

Table 4.5 Percentage of the consumption of different food groups by the gender of the household head 150

Table 4.6 Percentage of the consumption of different food groups by the gender of the person who manage household expenditures.

Table $5.1 \quad$ Correlations of explanatory variables with the dependent variable HDDS

Table 5.2 Result of the OLS estimation (full sample) 160

Table 5.3 Result of the OLS estimation (Sector-vise samples) 163 


\section{List of Figures}

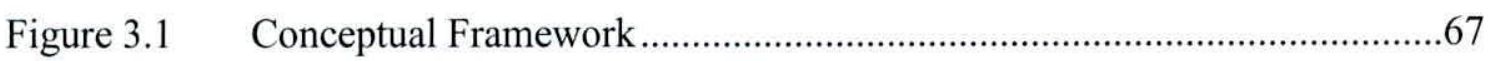

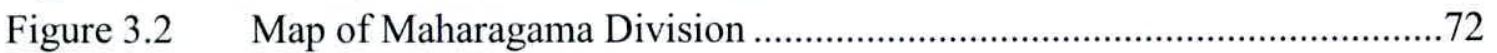

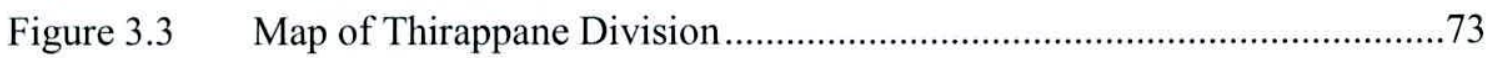

Figure 3.4 Dimensions of Food Security ……..........................................................96

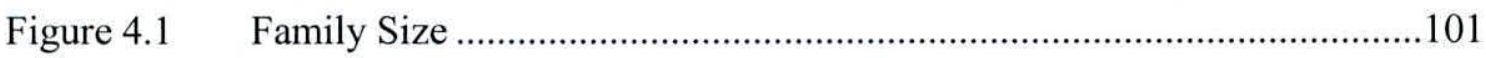

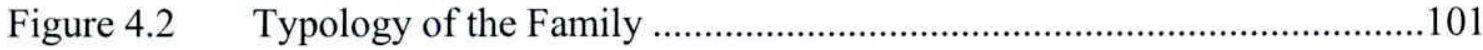

Figure 4.3 Gender of the Household Head ................................................................... 102

Figure 4.4 Marital Status of Female Household Head ................................................102

Figure 4.5 Primary Woman of a Household................................................................. 103

Figure 4.6 Educations of the Household Head.............................................................104

Figure 4.7 Education Differences of Male and Female Household Heads ................105

Figure 4.8 Education of the Primary Women..........................................................106

Figure 4.9 Urban-Rural difference of the Education of the Primary Women............106

Figure 4.10 Household Total Income - Rural Sector .................................................107

Figure 4.11 Mean Household Income .......................................................................... 109

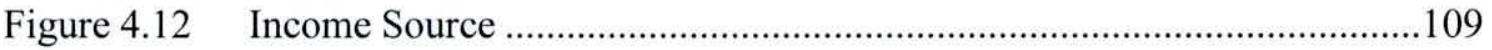

Figure 4.13 Household Total Expenditures..................................................................110

Figure 4.14 Household Dietary Diversity Score …....................................................111

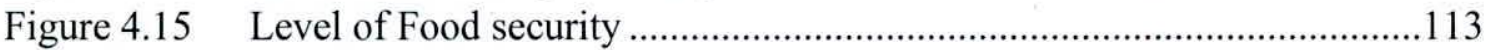

Figure 4.16 Level of Food Security: Urban- Rural ...................................................113

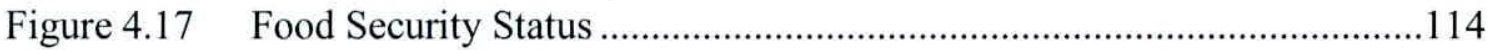

Figure 4.18 Food Security with Education of the Household Head............................115

Figure 4.19 Food Security with Family Size............................................................115

Figure 4.20 Female Contribution for Agricultural Activities........................................117

Figure 4.21 Female Contribution to Livestock Farming ...........................................118

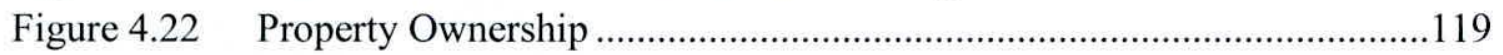

Figure 4.23 Food crop growing for Home Consumption ….....................................120

Figure 4.24 Responsibility of Food crop growing at Household Level ......................121

Figure 4.25 Food Security with Home Gardening of Food Crops ..............................121

Figure 4.26 Female Income in the Household ...........................................................122

Figure 4.27 Female Income with the Gender of the Household Head .........................123

Figure 4.28 Food Security with Female Income ......................................................123

Figure 4.29 Female Share of Household Income ......................................................125

Figure 4.30 Female Share of Household Income with

Figure 4.31 Food Security with Female Share of Household Income .........................127

Figure 4.32 Food Security with the Education of the Primary Women .......................128

Figure 4.33 Women's Status in the Household ............................................................129

Figure 4.34 Gender of the Person Who Manage Household Expenditures..................130 
Figure 4.35 Timing of Household Income Flows ……….........................................131

Figure 4.36 Smoothing Household Consumption …………….................................132

Figure 4.37 Debt Reason ..............................................................................132

Figure 4.38 Smoothing Household Consumption with Female Income Share ............133

Figure 4.39 Smoothing Household Consumption with the Gender of the Person Who Manage Household Expenditures ...............................134

Figure 4.40 Food Security with the Level of Smoothing Household Consumption...........................................................................135

Figure 4.41 Maintaining Food Stocks with the Education of Primary Women ...........136

Figure 4.42 Food Security with the Maintaining Food Stocks.....................................137

Figure 4.43 Food Security with the Use of Indigenous Knowledge ............................138

Figure 4.44 Use of Indigenous Knowledge by Sector...............................................138

Figure 4.45 Food Preparation in Household ...........................................................140

Figure 4.46 Household Intention on Preparing Nutritional Diets ..............................141

Figure 4.47 Intention of Preparing a Nutritious Diet with the Education level of the Primary Woman....................................................142

Figure 4.48 Food Security with Intention of Preparing Nutritional Diets....................143

Figure 4.49 Consumption of Foods Prepared Outside the Home..................................144

Figure 4.50 Food Consumption Differences by sector...............................................145

Figure 4.51 Food Consumption Differences by Female Share of

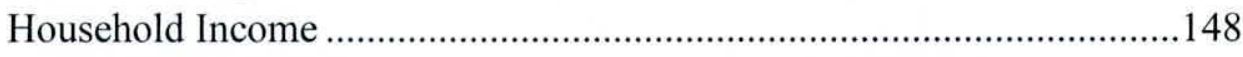

Figure 4.52 Consumption Differences by the Education of Primary Women .............149

Figure 4.53 Consumption Differences by the Gender of the Household Head............151

Figure 4.54 Consumption Differences with the Female Control over Household Spending ...................................................................152

Figure 5.1 Regression diagnostics- Normality of Regression Residuals ...................167

Figure 5.2 Regression diagnostics- Distribution of residuals ....................................167 


\section{Abbreviations}

$\begin{array}{lll}\text { DCS } & - & \text { Department of Census and Statistics } \\ \text { DS } & - & \text { Divisional Secretariat } \\ \text { FAO } & - & \text { Food and Agricultural Organization } \\ \text { GN } & - & \text { Grama Niladari } \\ \text { HDDS } & - & \text { Household Dietary Diversity Score } \\ \text { IDRC } & - & \text { International Development Research Centre } \\ \text { IFAD } & - & \text { International Fund for Agricultural Development } \\ \text { IFPRI } & - & \text { International Food Policy Research Institute } \\ \text { OLS } & - & \text { Ordinary Least Square } \\ \text { UNDP } & - & \text { United Nations Development Programme } \\ 2 \text { 2SLS } & - & \text { Two Stage Least Square }\end{array}$




\section{Acknowledgements}

I would like to extend my gratitude first and foremost to my supervisor, Dr. D.P.S. Chandrakumara, a senior lecturer of the Department of Economics, for the encouragement, guidance and assistance without which this study would have been impossible. I am extremely grateful for all the discussions and feedbacks which constantly served as a source of encouragement.

I am extremely grateful to Dr. Dhammika Withange, the former head of the department of the Department of Economics, for her supportive role in all administrative tasks.

I wish to extend my sincere appreciation to Dr, Shirantha Heenkenda, Mr. Gamini Weerasinghe and Mr. Ajantha Kalyanarathne, senior lecturers of the Department of Economics for their support and motivation to make this a success.

I would like to acknowledge immense support and time consuming contribution made by Mrs. Sujeewa Sebastian Pereira, senior lecturer of the Department of English in the process of editing. I wish to acknowledge with gratitude all the encouraging discussions we have had at the university over a cup of tea.

I wish to express my gratitude to Mr. Hemantha P. Diyunugala, senior Lecturer in the Department of Social Statistics, for the support rendered in numerous ways throughout the process of data analysis.

Further, the completion of this study would have been impossible without the support rendered by the Assistant Divisional Secretariat of Maharagama, the Assistant Divisional Secretariat of Thirappane and the Assistant Director (planning) in Thirappane DS, Mr. Ravindra Rathnayake in the process of data collection.

I take this opportunity to thank Ms.Imanga Nadeeshani, Mr, Anura Jayasinghe and Ms. Waruni Iresha for their support rendered me in different ways throughout the process.

A big thank goes to Mrs. Ajitha, Mr. Sami and Mr. Dharmadasa who always played a supportive role in the department.

I would like to extend my immense gratitude and love to my mother and my husband for their unconditional love, support and understanding.

Last but not least, thank you very much my little daughter, Lehansa, for your unspoken love which day by day built up hope and strength within myself to complete what I started with patience and determination. A huge apology my angel... for letting your childhood days fly while I'm here and not here with you at the same time!! . The sacrifices you made throughout the period is incomparable.

Wasana Kalansooriya

Department of Economics

University of Sri Jayewardenepura

August 2014 


\title{
Women's role in Household Food Security in the Urban-Rural Contexts of Sri Lanka
}

\section{Chandanee Wasana Kalansooriya}

\begin{abstract}
Food security is a major development concern in the current world and there is an increasing trend of directing food security policies towards the empowering women, because, many studies reveal that women play a major role in assuring the household food security. However, there is a dearth of studies that discusses the women's role in food security in the context of Sri Lanka, even though women are culturally assumed a huge responsibility in all most all the household tasks. Therefore, this study tries to analyse the impact of women's role on household food security in Sri Lanka in the urban rural contexts.
\end{abstract}

In order to achieve the objectives of the study, the primary data was obtained from 200 households which were selected from Maharagama urban council area to represent the urban sector and from the Thirappane AGA division to represent the rural sector. Both descriptive as well as econometric methods were used in the data analysis and a regression model was estimated using the OLS method.

According to the results, the study concluded that the women play an immense role in all three dimensions of food security; availability, access and utilization, within the Sri Lankan households. Women's income, education, their interests on preparing nutritious diet and the growing of food crop at household level were found as positive 
contributors for the household food security, while the gender of the household head was not a significant factor for the food security of a household. Further, the study found some striking differences of the role women play in assuring household food security between the urban and rural households. Finally, the results suggest that the food security policies in the country should be aimed at empowering women's capacities to yield better outcomes. 


\section{Chapter One}

\section{Introduction}

\subsection{Background of the study}

Food security, being one of the major issues of the present development dialogue, has been prioritized in domestic economic policies of many developing countries and also in the agendas of many international organizations especially in Food and Agriculture Organization (FAO). According to the definition put forward by FAO (1996), food security exists when all people at all times have the access to sufficient, safe and nutritious food to maintain a healthy and active life. Most of the developing countries are struggling to assure the food security in their countries with increasing food prices, decreasing arable agricultural lands, increasing population pressure, existence of poverty and with the adverse effects generated by climate changes, etc.

Generally, food security can be analyzed in two levels; macro level and micro level. The macro level or national level food security mostly aims at the food availability aspects, while the micro aspects focus on household or individual food acquirement and utilization aspects. Hence, the micro level food security or the household food security depends on many factors such as agricultural production, market availability of food either through national production or imports, income earning opportunities of household members, food aids received by the households, intra household decision making, resource allocation and responsibility sharing, care practices in households, and health care given to the household members, etc. Considering all the above factors, household food security can be considered as a multidimensional- multi facets issue which needs an 